Article

\title{
Rockfall and Debris Flow Hazard Assessment in the SW Escarpment of Montagna del Morrone Ridge (Abruzzo, Central Italy)
}

\author{
Monia Calista *, Valeria Menna, Vania Mancinelli, Nicola Sciarra $\mathbb{D}$ and Enrico Miccadei $(\mathbb{D}$ \\ Department of Engineering and Geology, Università degli Studi “G. d'Annunzio" Chieti-Pescara, \\ Via dei Vestini 31, 66100 Chieti Scalo (CH), Italy; vale93m@libero.it (V.M.); vaniamancinelli@gmail.com (V.M.); \\ nsciarra@unich.it (N.S.); miccadei@unich.it (E.M.) \\ * Correspondence: monia.calista@unich.it
}

Received: 20 March 2020; Accepted: 21 April 2020; Published: 23 April 2020

check for updates

\begin{abstract}
The purpose of this research is to estimate the rockfall and debris flow hazard assessment of the SW escarpment of the Montagna del Morrone (Abruzzo, Central Italy). The study investigated the geomorphology of the escarpment, focusing on the type and distribution of the present landforms. Particular attention was devoted to the slope gravity landforms widely developed in this area, where the effective activity of the gravitational processes is mainly related to the rockfall and debris flows and documented by numerous landslides over time. Working from orography, hydrography, lithology, and geomorphology, the landslide distribution and their potential invasion areas were evaluated through two specific numerical modeling software. RAMMS and Rockyfor3D calculation codes were used in order to analyze the debris flow and rockfall type of landslides, respectively. The obtained results are of great interest when evaluating the hazard assessment in relation to the potential landslides. Moreover, the geographic information systems (GIS) provide a new geomorphological zonation mapping, with the identification of the detachment and certain and/or possible invasion areas of the landslide blocks. This method provides an effective tool to support the correct territorial planning and the management of the infrastructural settlements present in the area and human safety.
\end{abstract}

Keywords: debris flow; rockfalls; numerical modeling

\section{Introduction}

Landslides are remarkable natural hazards linked to the combination of geological, geomorphological, and climatic factors (instability factors) in response to triggering mechanisms, mostly represented by heavy rainfall events, seismicity, or human action [1]. The landslide hazard and risk have become a theme of major interest due to the rising consciousness of the socio-economic implication of the landslides (economic, human, and environmental losses worldwide) and the increased impaction of the urbanization development [2]. The prediction of susceptible locations and hydrological scenarios contributing to landslides is essential for developing landslide mitigation strategies [3].

In mountainous areas, the shallow landslides hazard assessment represents an important aspect of land management. It requires the estimate of both the territory propensity to fail and the probability of the occurrence of the phenomena in time [4].

The present work focuses on the landslide hazard assessment of the SW escarpment of the Montagna del Morrone, one of the main Central Apennines ridge located in the Abruzzo Region (Central Italy). The Montagna del Morrone ridge is located between the Maiella Massif to the NE and the Sulmona Basin to the west. It is characterized by a landscape that evolved as a result of the continuous combination of tectonics, regional uplift, and selective erosion [5-9]. 
This ridge is made of carbonate lithological sequences pertaining to different Mesozoic-Cenozoic structural and palaeogeographic domains. It is made of an asymmetrical anticline fold with an NW-SE axis, NE verging, separated from the Sulmona Basin by several normal fault systems, NW-SE striking and SW dipping [10-12].

Several times in the past, this area was characterized by seismic events, debris avalanches, fires, and numerous landslide events. The landslide phenomena are mainly related to well-documented rockfall and debris flow events.

The rockfalls and debris flow hazard assessment of Montagna del Morrone area were investigated through multidisciplinary analyses that combined previous morphometric and slope analyses, geological and geomorphological field surveys, geomechanical investigation, orthophoto interpretation, and UAV survey [13] with numerical modeling simulations. The detailed field observations allowed to characterize lithological and tectonic features of the bedrock and the superficial deposits, as well as the type and the distribution of the main structural, gravity-induced and due to running waters landforms. All these available data combined with numerical modeling analyses made it possible to evaluate the most critical and failure areas, landslide blocks trajectory, and their related invasion areas.

The landslide hazard of the Montagna del Morrone ridge was estimated through two specific simulation softwares that require different input parameters in order to analyze debris flow and rockfall, respectively RAMMS and Rockyfor3D. Particularly, the RAMMS simulation investigated the velocities, the flow heights, the depositions areas, and the impact force of channeled debris flows phenomena (intermediate between the landslides or rockfalls and the fluvial sediment transport) [14]. These are possibly triggered by the rainfall, snowmelt, and/or other mass movements. Rockyfor3D made it possible to simulate the trajectories of single, individually falling rocks, in three dimensions and to assess the probability of arrival of blocks of certain sizes [15].

A geographic information systems (GIS) applied to the obtained results helped to identify a new geomorphological zonation of the escarpment, where detachment and certain and/or possible invasion areas of the landslide blocks were classified.

Rockfalls and debris flow events largely occur within the chain area (i.e. Colle Affogato-1783 $\mathrm{m}$ a.s.l., and Colle della Croce-1901 m a.s.l—alignment), and at the junction between the chain area and the piedmont (St. Onofrio Hermitage and Pacentro village). Their presence is correlated to geomorphological and topographic variables (i.e. slope, curvature, and vegetation cover) [3] and geomechanical factors that characterize the rock such as rock strength, tectonic discontinuities, hydraulic conditions, rock mass weathering mass [16].

Due to the extreme speed of rockfalls $[17,18]$ and the destructive nature of debris flows, which rapidly move large volumes of heterogeneous sediments (fluid mixtures of water, clay, granular materials, rock blocks), these phenomena represent a constant hazard for structures, buildings, and population safety [19].

\section{Study Area}

The Montagna del Morrone ridge is located in the central-eastern sector of the Abruzzo Region and it is one of the main carbonate ridges of the Central Apennines chain [13]. On the western side, it is bounded by the Sulmona Basin; while on the eastern side, the N-S striking Caramanico Valley separates the ridge from that of Montagna della Maiella [13,20]. The Montagna del Morrone is an NW-SE straight ridge of $20 \mathrm{~km}$ of length, with asymmetric transversal profile and steep SW and NE slopes [20]. It is characterized by great variation in height and by a high amplitude of relief. From NW to SE, Schiena d'Asino (1498 m a.s.1.), Colle Affogato (1783 m a.s.1.), Colle della Croce (1901 m a.s.l.), Mt. Morrone (2061 m a.s.1.), Mt. Cimerone (1849 m a.s.1.), and Mt. Mileto (1920 m a.s.1.) are the main aligned peaks of Montagna del Morrone.

According to the orography of the landscape, three different sectors are evidenced (Figure 1). The northernmost sector, between the Gole di Popoli and Roccacasale village, is characterized by the M. Schiena d'Asino (1498 m a.s.1.) and Colle Affogato (1783 $\mathrm{m}$ a.s.1.) sharp alignment, where the highest 
slope inclinations are reached (>100\%). Towards the valley, the slope shows a weakly undulating morphology area, reaching slope inclination between $0 \%$ and $20 \%$ and height from 650 to $950 \mathrm{~m}$ a.s.l. The lower segment has a slope inclination between $30 \%$ and $50 \%$ and it develops from $350 \mathrm{~m}$ to $650 \mathrm{~m}$ a.s.1.

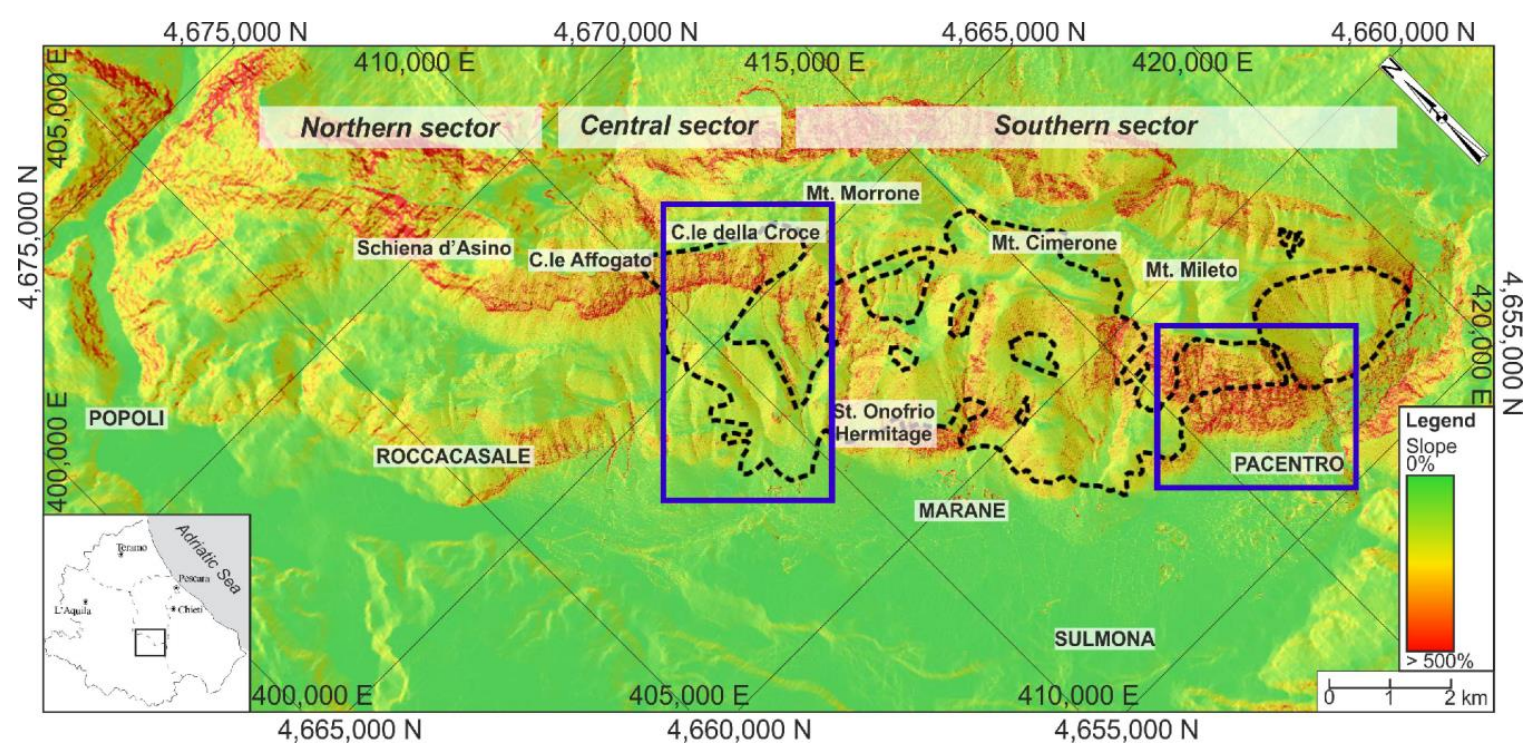

Figure 1. Slope map of the Montagna del Morrone ridge. The blue boxes highlight the location of the study area; the black dashed area indicates the 2017 Montagna del Morrone fire (modified from Carabella et al., 2019).

The central sector, between Colle Affogato and St. Onofrio Hermitage, features a variable morphology, with wide scarps and valleys. It is segmented into three zones of differing elevation and slope value: the northernmost area develops from $900 \mathrm{~m}$ a.s.l. up to the summit of Monte Morrone (2061 m a.s.1.), with slope inclination of 70\%, locally 100\%; the mid-portion extends from 750 to $900 \mathrm{~m}$ a.s.l. showing an average slope inclination of 35\%; the lower part, from 475 to $750 \mathrm{~m}$ a.s.l., features a slope inclination of $\sim 50 \%$.

The southern sector, between St. Onofrio Hermitage and Pacentro village, is the most massive sector of the ridge. It is characterized by a high and steep segment, with a slope inclination of $60 \%$ (locally 100) from the base of the slope (550-600 m a.s.1.) to $1700 \mathrm{~m}$ a.s.l., and a weakly irregular zone (0\%-30\%) which extends up to the Mt. Le Mucchia (1986 m a.s.1.) and Mt. Mileto (1920 m a.s.l) alignment.

The central and southern sector of the SW side of the ridge were involved in the great 2017 fire, particularly in the area between Colle Affogato and Pacentro village. It occurred over a total duration of 24 days and burned about 2200 ha. The fire developed on the 19 of August with different severity levels along the entire slope and according to the vegetation cover and lithological features. The first affected area was the Pacentro village; the fire slowly descended towards the junction with the Sulmona Basin, worsening the landslide hazard of the examined area (Figure 1). Indeed, the decrease in vegetation cover leads to an increase in the infiltration rate that appears to favor the initiation of mass movements, as documented by recent gravity-induced events [13].

The hydrography of the study area is made of ephemeral stream channels, which flow in the NE-SW direction and, at the base of the slope, converge into the Vella River, which crossed the Sulmona Basin. The drainage network shows a mainly sub-parallel pattern.

The SW escarpment of Montagna del Morrone is subdivided into 21 basins with a complex organization and variable geometry. Some of them are located on the upper slope and are endorheic, others develop from the principal crest line to the base of the slope, others are set on the mid-slope with a closure in the toe-slope, or across the toe- and mid-slope as hydrographic units. They present 
elongated, squared, or sub-circular shape and a parallel pattern, locally with sub-dendritic sections (Colle della Croce-Colle Affogato) [13].

The area is also characterized by an intense seismicity and historical strong earthquakes [21] connected to the present-day extensional tectonics. Focusing on $\mathrm{Mw}>4$ events, 86 seismic events were recorded in the L'Aquila area from 1315 to 2020 (with Mw 6.7 in 1703 and Mw 6.3 in 2009 maximum events), 8 events in the Maiella area from 1349 to 1933 (with the strongest Mw 6.8 event in 1706 and 5.9 in 1933), 42 events in the Marsica area from 1579 to 2020 (up to Mw 7 in 1915).

\section{Geomorphological Data}

The Montagna del Morrone evolution is associated with the control of both morphostructural and morphosculptural factors, respectively connected to tectonic dynamics and regional uplift, gravity-induced slope processes and drainage network development [22].

The faults scarps and fault-line scarps are the main structural landforms in the area. Associated with the main fault lines and placed at different heights along the slope [23,24], they consist of straight rock scarps from 10 to $100 \mathrm{~m}$ high, partly or totally covered by surface deposits (Figures 2 and 3).

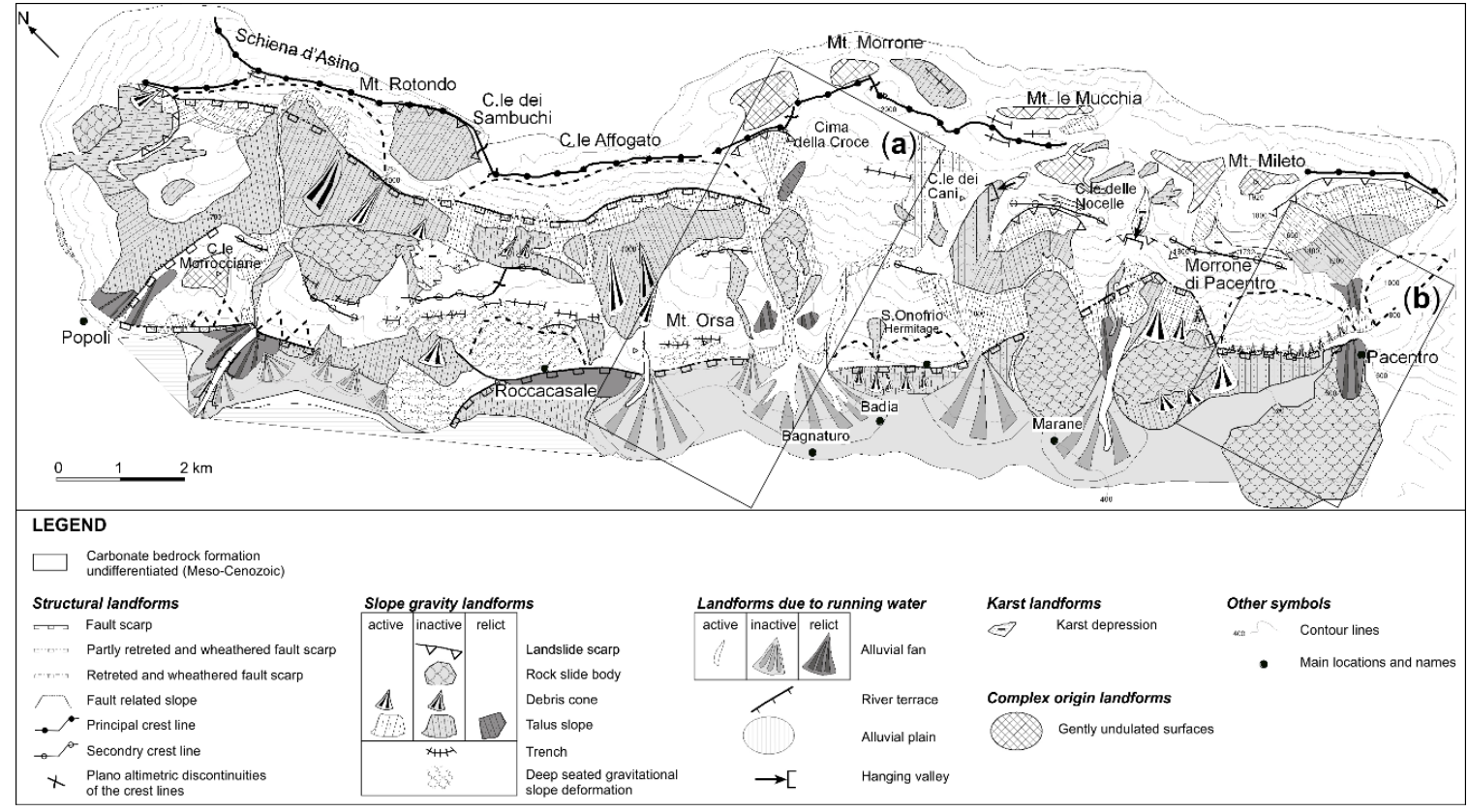

Figure 2. Geomorphological map of the study area, (modified from Miccadei et al., 2004 [20]). The (a) and (b) boxes indicate the study area.

Free faces, with slope gravity denudation evidence and locally linked to channel flow and nivation actions, are found in the summit area of fault scarps; while the base of the scarps shows mostly inactive debris deposits. Slope gravity forms are the most present forms in the area. In a general NW-SE orientation and at heights of 2-3 m, rock scarps affected by rockfalls are placed along Colle Affogato and Colle della Croce alignment, as well as near St. Onofrio Hermitage and Pacentro village. The landslide scarps (1000-3000 m wide) develop in the arched or semi-circular rock scarps and they are placed in the calcareous bedrock, weathered and shaped by further gravity-induced processes. The debris flow channels, widely spread in the area, are parallel to the main slope direction and they are affected by polygenic processes (i.e., debris discharge, water runoff, snow avalanches). The talus slope and debris cone are present along the whole slope, especially in Colle della Croce area (1300-700 $\mathrm{m}$ a.s.l.), St. Onofrio Hermitage (600-400 m a.s.1.), and downstream Mt. Mileto (600-800 m a.s.1.). They are both set on the bedrock units and superficial covers and formed by heterogeneous calcareous material with heterometric blocks, generally graded proceeding towards the base of the cone. Placed in St. Onofrio 
Hermitage and Marane areas, debris flows are present at the toe-slope and they are formed by chaotic materials, with low selection and aligned clasts in correspondence of the base of the invasion area. The rockslide bodies are distributed both at the toe-slope and in the same mid-part points. They are made of large limestone blocks and of heterometric carbonate breccias in a chaotic arrangement with rich clay-silt matrix, or of limestone stratified rock with the original lithostructural arrangement.

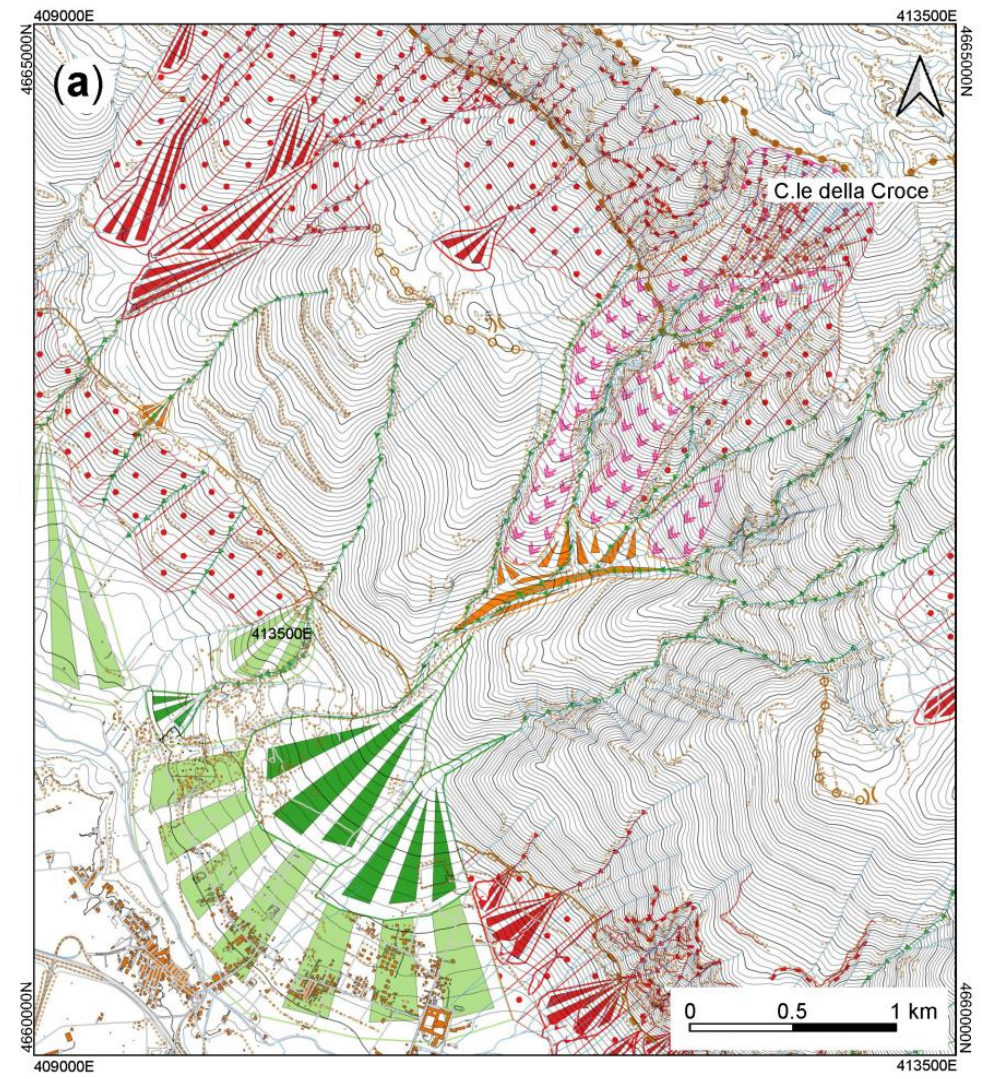

LEGEND

Structural landforms

Saddle
Principal crest line
Secondary crest line
Fault scarp
Wheathered fault scarp

\section{Slope gravity landforms}

\begin{tabular}{|c|c|c|}
\hline $\begin{array}{l}\text { Rock scarp affected } \\
\text { by rockfalls }(<5 \mathrm{~m})\end{array}$ & Active & Quiescent Inactive \\
\hline $\begin{array}{l}\text { Rock scarp affected } \\
\text { by rockfalls }(5-10 \mathrm{~m})\end{array}$ & $\pi$ & \\
\hline $\begin{array}{l}\text { Rock scarp affected } \\
\text { by rockfalls }(>10 \mathrm{~m})\end{array}$ & $\cdots$ & \\
\hline $\begin{array}{l}\text { Rock gully with } \\
\text { debris discharges }\end{array}$ & $\rightarrow$ & \\
\hline Debris cone & $\mathbb{A}$ & $\mathbb{A}$ \\
\hline Talus slope & :1::8: & \\
\hline Debris flow heaps & $v_{v v}$ & \\
\hline Landslide scarp & & $\cdots$ \\
\hline Landslide body & & $\Xi \approx$ \\
\hline \multicolumn{3}{|c|}{ Landforms due to running water } \\
\hline & Active & Quiescent Inactive \\
\hline U shaped-valley & [ [ ] & \\
\hline Gullies & $\leftrightarrow$ & \\
\hline Alluvial fan & $\mathbb{A}$ & $\Delta$ \\
\hline
\end{tabular}

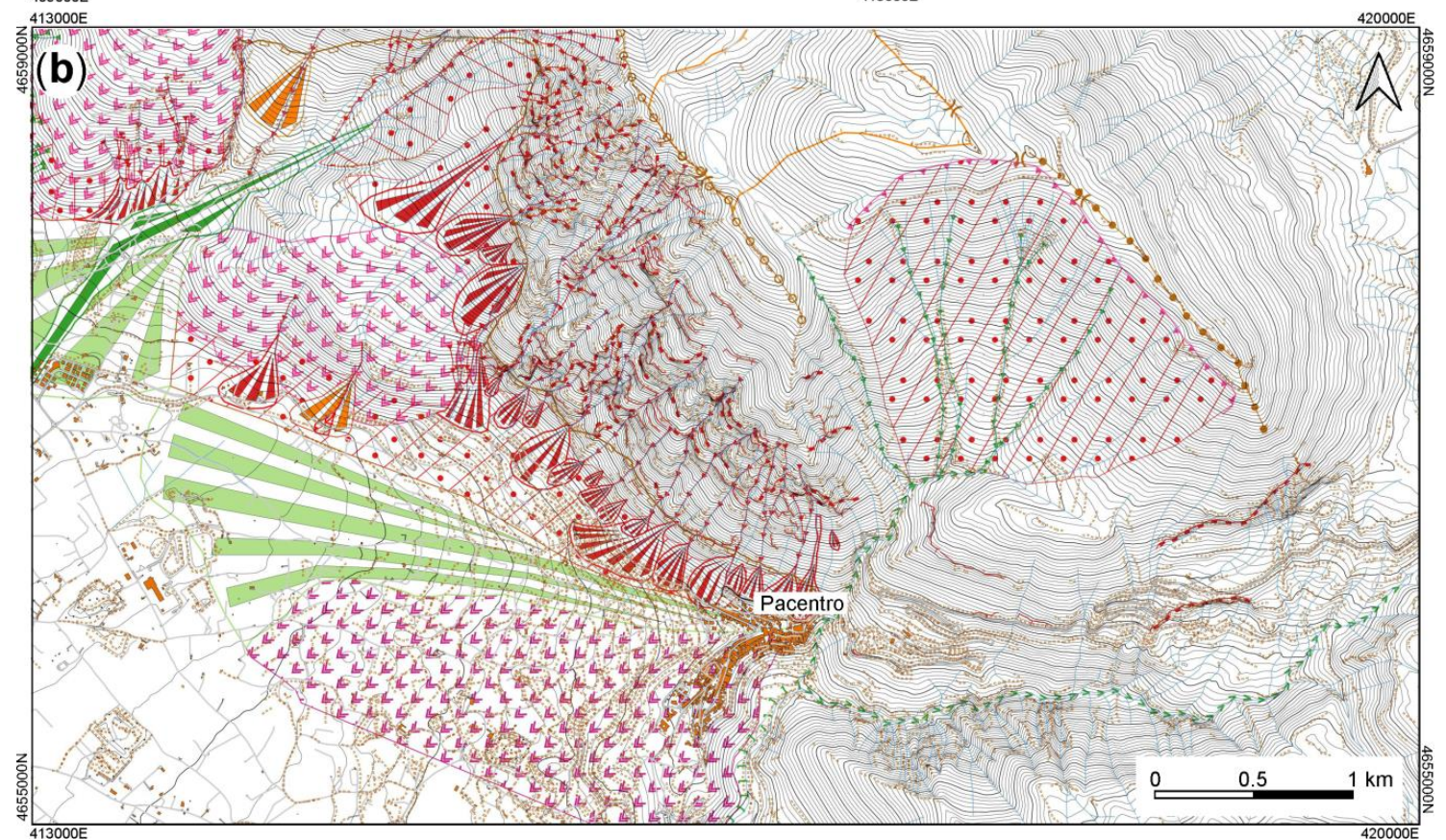

Figure 3. Geomorphological map extracted from Sciarra et al., 2018 [24] Colle della Croce area (a); Pacentro area $(\mathbf{b})$. 
Geomechanical investigations were performed in order to verify the bedrock fracturing and to outline the possible landslide mechanisms and the dimensions of the involved blocks. A detailed scan line survey was carried out and a kinematic analysis was performed at four different sites selected according to their geological and geomorphological features. The statistical analysis of discontinuity orientation and spacing and their relationship with slope orientation allowed us to analyze the joint spacing, persistence, and discontinuity sets. In detail, the main discontinuity sets were oriented at N30W 60SW and N78E 70SE, and their spacing and persistence allowed us to infer the size of unstable blocks of large $\left(\mathrm{Jv}=1 / 3\right.$ joint $\left./ \mathrm{m}^{3}\right)$ to medium $\left(\mathrm{Jv}=3 / 10\right.$ joint $\left./ \mathrm{m}^{3}\right)$ sizes [13].

Among the landforms due to the running waters, gullies and alluvial fans are found. Gullies are present on the northern, central, and southern sectors of the slope with N-S, NE-SW directions. Alluvial fans are mostly placed at the junction with the Sulmona Basin, with apexes in correspondence to the basal border fault downstream of the gullies next to Pacentro and Marane village. These are generally inactive forms.

\section{Main Past Landslide Events}

The study area shows a Mediterranean to warm temperate mountainous climate type, with a general bimodal pattern marked by an absolute maximum in autumn and a relative one in spring, and an absolute minimum in summer. The average annual precipitation is $700-1400 \mathrm{~mm} /$ year, with occasional heavy rainfalls (>100 mm/day and 30-40 mm/h) [13]. The average monthly precipitations are resumed in Figure 4. These data were evaluated through the analysis of the main Montagna del Morrone pluviometric stations, from a 30-year time record source (1987-2017).

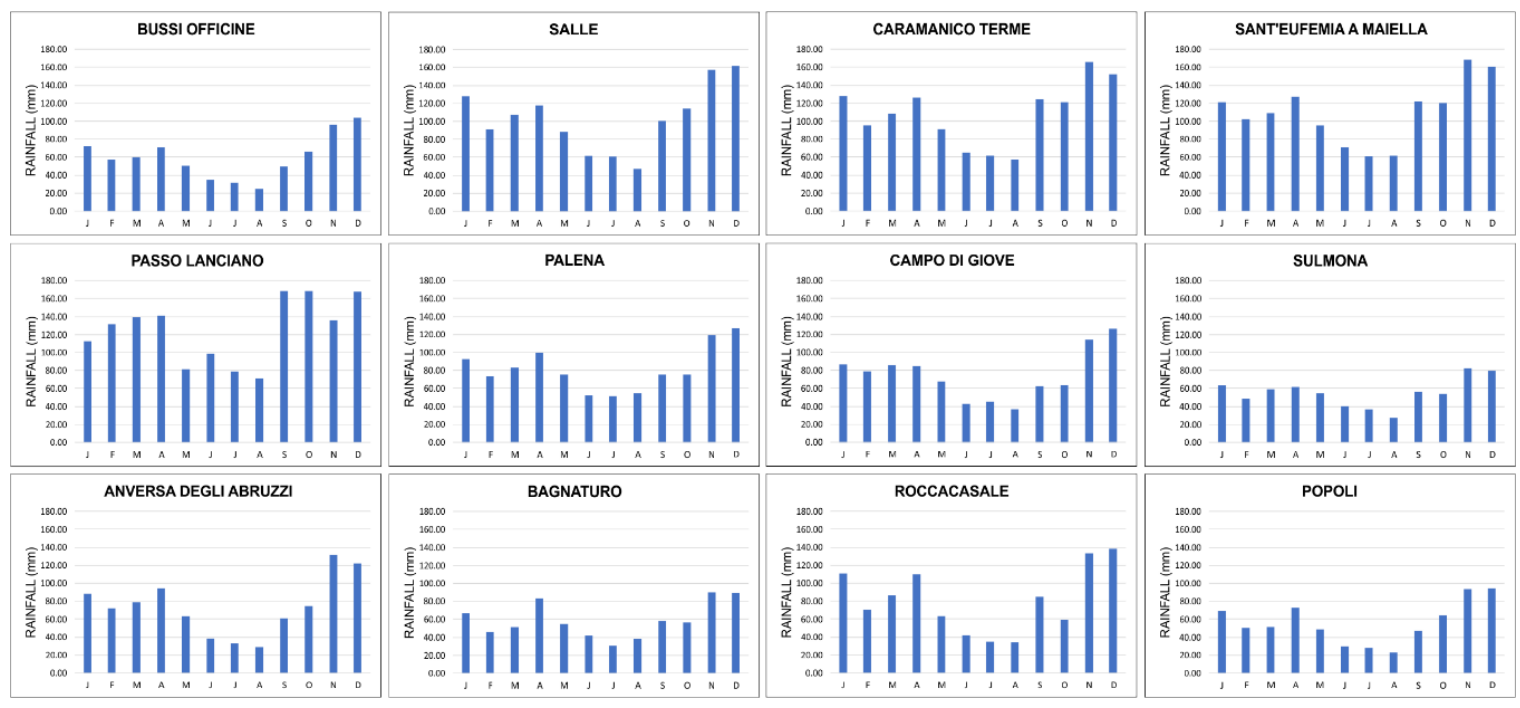

Figure 4. Pluviometric regime of main Montagna del Morrone pluviometric stations (data from 1987-2017).

Due to the orography (elevation, slope, and energy of relief), hydrography (drainage network and pattern), climatic conditions (recent heavy precipitations), and geological-geomorphological characteristics, gravity-induced events occurred several times in the past, as documented by reported events and field mapping. The field observations also revealed that there are no seism-induced landslides.

Most of the landslide events were recorded in the AVI Project [25] and 2017 ISPRA database [26], others come from Carta delle Valanghe [27] and local newspapers [28] (Table 1). These events are mainly related to triggering factors as heavy precipitations, crioclastism, fracturing, and the 2017 Montagna del Morrone fire for the most recent landslide phenomena. They involved rock blocks from decimetric to metric dimensions, damaging urban and infrastructural settlements (i.e., interruption 
and closure of the SP n.13 and SR n.487 roads to Pacentro) and causing inconveniences for inhabitants (i.e., uprooting of trees, folding of retaining walls).

Table 1. Historical analysis of past events.

\begin{tabular}{|c|c|c|c|c|}
\hline Municipality & Locality & Date & Type of Event & Source \\
\hline Pacentro & Guado San Leonardo & 1973 & Rockfall & AVI Project \\
\hline Pacentro & San Rocco & 1984 & Rockfall & AVI Project \\
\hline Pacentro & $\begin{array}{c}\text { Balze del Morrone } \\
(\mathrm{SP} \text { n.13 from km } 1+100 \text { to } \mathrm{km} 1+400)\end{array}$ & 1989 & Rockfall & AVI Project \\
\hline Pacentro & Caldora Castle & 2004 & Rockfall & Local inventories \\
\hline Pacentro & km 44+033 SP n.13 & 2014 & Rockfall & https://report-age.com \\
\hline Pacentro & SR n. 487 km 45-46 & 2015 & Rockfall & Local inventories \\
\hline Pacentro & Balze del Morrone & 2015 & Avalanches & Carta Valanghe \\
\hline Pacentro & Caldora Castle & 2017 & Debris flow & 2017 ISPRA database \\
\hline Pacentro & Passo San Leonado & 2017 & Rockfall & 2017 ISPRA database \\
\hline
\end{tabular}

\section{Methods}

Landslide hazard assessment of the SW escarpment of the Montagna del Morrone ridge was estimated through RAMMS and Rockyfor3D software in order to investigate respectively debris-flow and rockfall hazard. Numerical modeling was applied to specific sites selected through previous field observations [13]: morphometric and slope analysis, geological and geomorphological field mapping (1:5.000 scale, performed according to the Geological Survey of Italy and AIGeo guidelines) $[29,30]$, geomechanical investigation, orthophoto analyses, and UAV survey. In this way, the individuation of the hypothetical release areas was possible, where landslide phenomena are expected, considering the sites with the most critical failure conditions, lithological and tectonic features of the bedrock and superficial covers, as well as the type and the distribution of the main present and ancient geomorphological landforms (i.e., structural, slope gravity and due to running waters forms). Rockyfor3D and RAMMS are specific numerical models used in the evaluation of the evolution mechanism of the slope. They simulate the landslide blocks trajectory and the related invasion areas of different landslide types.

The possible inaccuracies of the friction parameters determination in RAMMS, and the uncertainties connected to the determination of the parameters in Rockyfor3D must be taken into account; moreover, each software required different input parameters, which are a function of the nature of the studied landslide process.

\subsection{Debris Flow Analysis}

The RAMMS (rapid mass movements simulation) code, used for the analyses on debris flow, is a numerical model planned for flow phenomena which predict the slope-parallel velocities and flow heights. It is used to calculate the motion of the movement from initiation to runout in a three-dimensional terrain.

The RAMMS code was applied along specific channels next to Colle della Croce and Pacentro areas, where, according to field observations, debris flow hazard is very high.

The most important input parameters requested are:

- $\quad$ digital elevation model -DEM- (2 m LIDAR - laser imaging detection and ranging);

- location and size of the released mass (debris flow detachment area);

- calculation domain: extension of the debris flow path;

- $\quad$ input hydrograph: the amount of material that might flow at a certain location in the channel;

- friction information: $\mu$ and $\xi$ friction coefficients (after explained); 
- angle of inflow direction with respect to the x-coordinate of the topographic data.

Specifically, the input hydrograph construction was based on the knowledge of the total volume, maximum discharge (amount of material that flows), and flow velocity which were calculated combining the field measurements (i.e., basin area and channel's length, slope inclination) with empirical relations $[14,31,32]$.

The major difficulty in RAMMS debris flow simulation is the choice of the friction parameters which requires careful calibration of the model by using depth-averaged equations and integrating reference information such as field data and measurements.

In this work, the calibration of the RAMMS model was carried out through a back-analysis procedure $[33,34]$ which mainly interested two fundamental parameters employed by Voellmy-fluid friction law: $\mu$, the frictional resistance which scales with the normal stress, and $\xi\left(\mathrm{m} / \mathrm{s}^{2}\right)$, the viscous-turbulent friction. Generally, $\mu$ ranges between 0.05 and $0.4 ; \xi$ is more delicate to calibrate but small values of $\xi(100-200)$ are reported for granular flows, relatively large $\xi(200-1000)$ values are sometimes related to muddy flows [35]. Moreover, $\mu$ dominates when the flow is close to stopping, $\xi$ dominates when the flow is running quickly. The calibration of $\mu$ and $\xi$ values is prime because RAMMS uses a single-phase model that cannot distinguish between fluid and solid phases modeling the material as bulk flow.

To get realistic and useful results, the calibration of the Voellmy friction model was done on the Marane debris flow. Following the destruction of vegetation due to the 2017 fire, an intense, short-duration rainfall event (with $\sim 95 \mathrm{~mm}$ of rainfall in $48 \mathrm{~h}$ ) triggered the debris flow event in the area of Casato Santa Lucia, near Marane village.

This extreme rainfall event, representative of the occasional heavy rainfalls which characterize the study area, occurred on the 15-16 of August 2018. In detail, the cumulative rainfall was about $90 \mathrm{~mm}$ in $12 \mathrm{~h}$, from 20:00 on the 15 of August to 08:00 on the 16 of August. The intensity was moderate, with low values ranging from 3 to $11 \mathrm{~mm} / \mathrm{h}$ and some peaks ranging from 18 to $22 \mathrm{~mm} / \mathrm{h}$ (Figure 5). These data refer to Sulmona station, the closest to the Marane area [13].
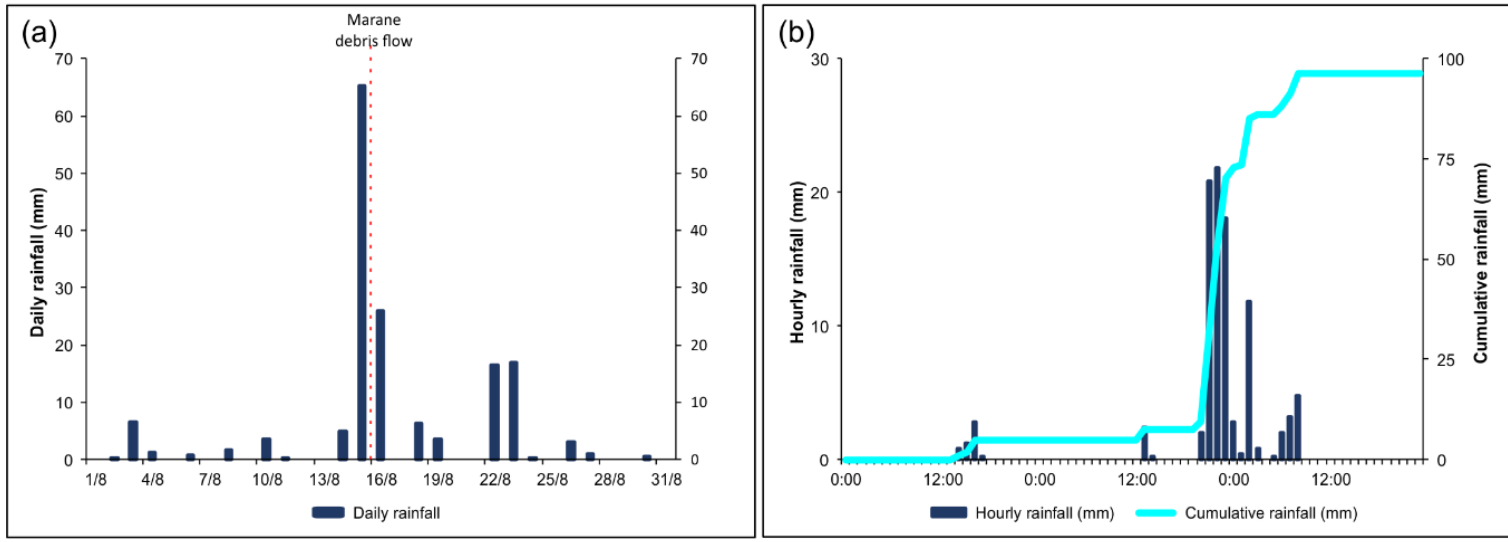

Figure 5. Sulmona pluviometric station: Daily rainfall in the month of August 2018 (a); hourly and cumulative rainfall during the event of 14-16 August 2018 (modified from Carabella et al., 2019) (b).

The calibration of resistance parameters was done by changing separately each friction parameter ( $\mu$ or $\xi$ ) and keeping constant the other $(\xi$ or $\mu$ ) [36-40]. Varying $\mu$ around the initial definition (with steps of \pm 0.01 and $\xi$ with steps of $\pm 50 \mathrm{~m} / \mathrm{s}^{2}$ ), several initial values of the Voellmy friction coefficients were applied in order to obtain numerical modeling results congruent with the Marane debris-flow event (Figure 6), in terms of flow heights and invasion area. The main friction coefficient combinations are resumed in Table 2. 

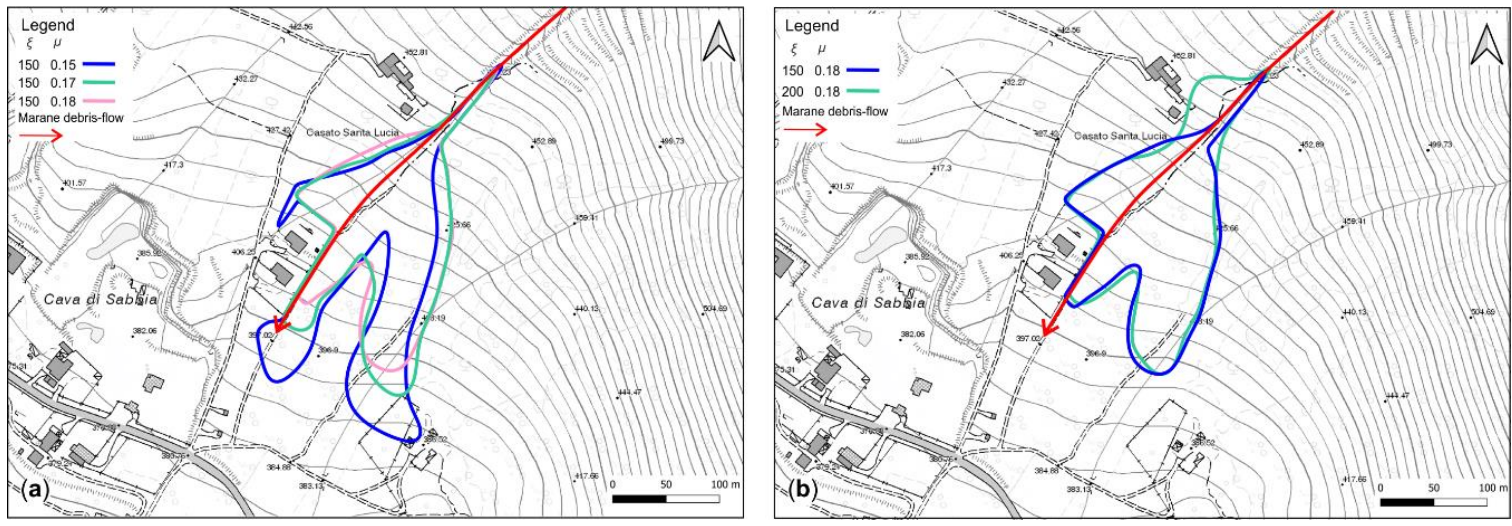

Figure 6. Calibration of the friction parameters $\mu$ and $\xi$ : fixing $\xi$ and varying $\mu(\mathbf{a})$; fixing $\mu$ and varying $\xi(\mathbf{b})$.

Table 2. Combinations of friction parameters $(\mu, \xi)$ used to calibrate RAMMS simulations.

\begin{tabular}{ccc}
\hline & $\mu$ & $\xi$ \\
\hline 1 & 0.15 & 150 \\
2 & 0.15 & 200 \\
3 & 0.18 & 150 \\
4 & 0.18 & 200 \\
5 & 0.17 & 150 \\
\hline
\end{tabular}

The best-fit found for the Voellmy friction coefficients indicates values of 0.17 for $\mu$ and 150 for $\xi$. These values were used to perform simulations both for the Colle della Croce and Pacentro sectors, which show similar debris flows, as documented by field observations.

RAMMS simulations highlighted that the maximum deposition values are found in the correspondence with Casato Santa Lucia, where the debris flow invasion area was sited. The resulting debris flow sediment deposition ( $>1 \mathrm{~m}$ of detritic material with blocks of variable dimensions) arrested next to the protection wall surrounding the two main houses (Figure 7), defined as obstacles in the RAMMS simulation.


Figure 7. Marane debris-flow: Detail of the debris-flow deposition (m) (a); detail of the invasion area $(\mathbf{b}, \mathbf{c})$. The black box indicates the location of $b$ and $c$ images.

In detail, among the 21 basins characterizing the SW escarpment of Montagna del Morrone, RAMMS simulations were carried out in Colle della Croce area along four specific channels $(C 1, C 2$, 
C3, and C4 in Figure 8) showing geomorphological features similar to that of Marane area (i.e., debris flow channel, debris cone, talus slope, type, and grain size of the transported solid material). Different simulations were carried out in order to estimate debris flow hazard along selected channels which were analyzed individually, in pairs and all together:

- $\quad$ Scenario 1: simulation along channel C1.

- $\quad$ Scenario 2: simulation along channel C2.

- Scenario 3: simulation along channel C3.

- Scenario 4: simulation along channel C4.

- Scenario 5: simultaneous simulation along channels C1-C2.

- Scenario 6: simultaneous simulation along channels C3-C4.

- $\quad$ Scenario 7: simultaneous simulation along channels C1-C2-C3-C4.

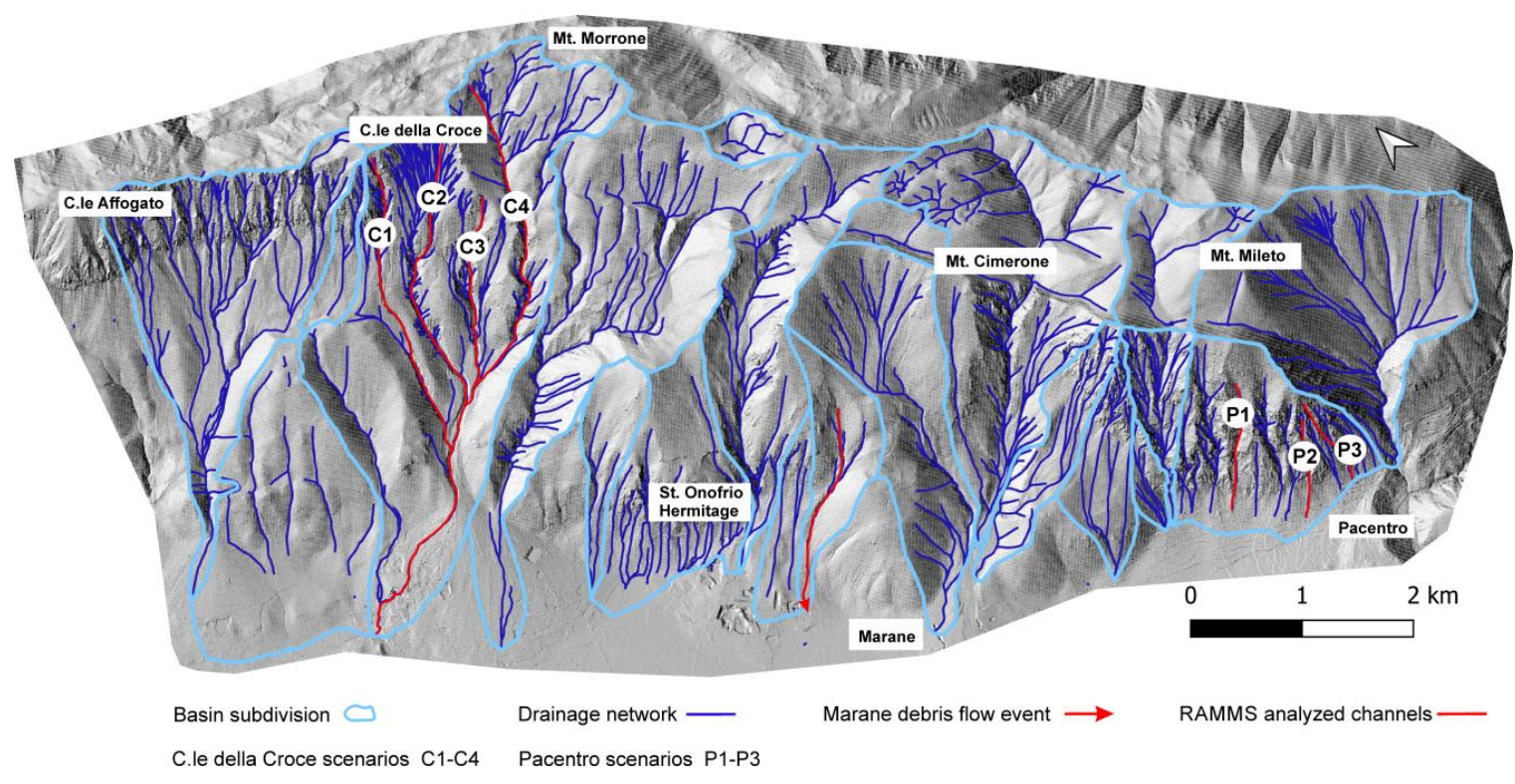

Figure 8. RAMMS scenarios along Colle della Croce and Pacentro areas.

In this way, it was possible to evaluate the variation of the invasion area and consequently of the debris flow hazard.

The RAMMS simulations for Pacentro area (P1, P2, and P3 in Figure 8) were performed along the main channels next to the village, where the rockfall hazard is also elevated.

\section{Rockfall Analysis}

Rockfall hazard assessment of the SW Montagna del Morrone ridge was investigated through Rockyfor3D simulation code (v5.2, [41]). This is a three-dimensional simulation code used for rockfall probabilistic simulations on a regional, local, and slope through the processing of different input parameters.

Working from the detachment areas, with the use of a digital elevation model (DEM), the evaluation of geological and geomorphological parameters and the protective action of the forest, Rockyfor3D calculates the fall trajectory in three dimensions (3D) for the individual rock blocks.

The trajectory of falling rocks is simulated with a vector that stores the three-dimensional values (of position and speed), through the calculation of a sequence of free falls of each block, according to the parabolic law of free fall in the air, and rebounds on the slope surface. If it is required, impacts against trees are also calculated. The rolling is represented with a sequence of rebounds at a small 
distance, with the analysis of the impacts on the ground and/or with the forest, as well as the energies involved; the sliding of the blocks is not modeled [15]).

Rockyfor3D simulations were applied to Pacentro area, in the southern sector of Montagna del Morrone ridge, because rockfalls, as well as other landslide geomorphological features, are widely spread and largely affect urban and infrastructural settlements downstream.

The main input parameters used in this work are:

- $\quad \operatorname{DEM}(2 \mathrm{~m} \times 2 \mathrm{~m})$ reconstructed through the UAV survey with a high-resolution camera.

- Volume weight of the materials: $2500 \mathrm{~kg} / \mathrm{m}^{3}$ for the cells considered possible sources of collapse, where more or less porous calcareous lithotypes outcrop.

- Size, shape, and volume variations of the blocks involved.

- Slope roughness: values ranging from: (a) 0 to $0.15 \mathrm{~m}$ in areas along the slope characterized by bedrock; (b) 0.02 to $0.1 \mathrm{~m}$ in areas where the substrate shows meteoric degradation material; (c) 0.1 to $0.6 \mathrm{~m}$ in areas with slope debris; (d) near the anthropic forms (roads, buildings) values equal to 0 were assigned.

- Land use: slope debris (value 4), bedrock with fine material of meteoric degradation (value 5), bedrock (value 6), and roads (value 7).

- Number of trees per hectare: maximum value of 1200 trees/hectare for areas with dense forest, minimum of 100 trees/hectare for sparse shrub areas; areas without vegetation have a value equal to 0 .

- Diameter of the trunks: from $30 \mathrm{~cm}$ in areas with dense vegetation and/or olive groves to $20 \mathrm{~cm}$ in areas with medium or sparse vegetation; if vegetation is absent, the value assigned is 0 .

- Variation in the diameter of the trunks: equal to $15 \mathrm{~cm}$ in areas with tree vegetation.

Once all the input parameters were acquired, the detachment areas of probable landslide phenomena were defined, working from the analysis of the minimum inclination values considered critical for rockfall triggering. Considering the geological and geomorphological context of the Pacentro slope, sectors placed in the upper part of the ridge, characterized by slope values $>37^{\circ}$ [42] and where calcareous bedrock outcrops, were selected as release areas.

According to the field surveys, to the analysis of the blocks accumulated along the slope, the debris present at the base of the slope and the general geo-mechanical conditions, parallelepiped shape blocks were chosen for simulation and four different cases were analyzed in order to evaluate the rockfalls hazard on the Pacentro area:

- Case 1: medium-large sized blocks $(1 \times 0.7 \times 0.5$ with $+/-20 \%$ volume variation $)$ with vegetation cover.

- Case 2: as Case 1 without vegetation cover.

- Case 3: modest sized blocks $(0.2 \times 0.2 \times 0.2$ with $+/-50 \%$ volume variation $)$ with vegetation cover.

- Case 4: as Case 3 without vegetation cover.

For each case, 10, 25, and 50 simulations were run (i.e., 10, 25, and 50 individual rockfall trajectories from each source cell were simulated).

The distribution and propagation of the blocks and their invasion areas were analyzed and compared for each simulation.

The results obtained are very similar to each other and the maps deriving from the run of 50 simulations are presented.

\section{Results}

Combined with previous field data analysis, debris flow and rockfall hazard of the SW escarpment of the Montagna del Morrone was evaluated.

Focusing on the flow heights and deposition (RAMMS) as well as 3D rockfall trajectory for the individual rock blocks (Rockyfor3D), the obtained results are presented in the following subsections. 
Using GIS technology (QGIS 2018, version 3.4 "Madeira"), RAMMS and Rockyfor3D results were separately analyzed and then overlaid in order to provide the identification and mapping of the detachment and certain and/or possible invasion areas. This study highlighted how numerical modeling, supported by detailed field surveys, strongly contributes to understanding landslide mechanisms and landscape changes.

\subsection{Colle della Croce Results}

Individually, in pairs, and simultaneously, four specific channels next to Colle della Croce area were analyzed. The obtained results are separately summarized and described in the following subsections.

\subsubsection{Single Channels Numerical Modeling Results}

When the four selected channels were considered singularly, numerical modeling results showed that the highest deposition values are recorded in NE of Schiappara area. In scenarios n. 1, 3, and 4, the sediments reach more than $1.50 \mathrm{~m}$ in thickness (Figure 9a,c,d), while in scenario n. 2 (Figure 9b), more than $2 \mathrm{~m}$ in thickness. The worst case is related to scenario 2 (Figure 9b), which is characterized by the highest debris flow deposition values; while the widest debris flow invasion area (410 $\mathrm{m}$ a.s.l.) is related to scenario n. 4 (Figure 9d) with $0.124 \mathrm{~km}^{2}$ of extension. All the values of invasion areas and minimum runout altitudes are resumed in Table 3.


Figure 9. Colle della Croce flow deposition (m) in scenario 1; (a); (b) scenario 2; (c) scenario 3; (c); scenario $4(\mathrm{~d})$. The altitude points (blue dots) refer to the minimum runout altitude of each scenario.

Debris flow mass perfectly follows the morphology of the channels and then generates the classic deposition cone downstream, in the areas with a steep decrease in slope, involving partly the local road network that connects to the SS17 road. 
Table 3. Invasion areas and minimum runout altitudes along Colle della Croce single channels.

\begin{tabular}{ccc}
\hline Colle Della Croce & $\begin{array}{c}\text { Minimum } \\
\text { Runout Altitude (m a.s.1.) }\end{array}$ & Invasion Area $\left.\mathbf{( k m}^{\mathbf{2}}\right)$ \\
\hline Scenario 1 & 455 & 0.038 \\
Scenario 2 & 438 & 0.064 \\
Scenario 3 & 455 & 0.040 \\
Scenario 4 & 410 & 0.124 \\
\hline
\end{tabular}

\subsubsection{Channels Pairs Numerical Modeling Results}

RAMMS analyses were also performed along pairs of selected channels: scenario 5 and 6 watercourses were investigated. In this way, the invasion area of debris flows was evaluated, assuming that they are triggered simultaneously along both the channels of each selected pair. In addition, the variation of the invasion area and debris flow hazard were estimated. Like single channels, sediment deposition values stopped in the NE of the Schiappara area, involving again the main infrastructural settlements. Debris flow invasion areas of scenario 5 and 6 have similar extension (Figure 10a,b) and they are slightly higher than that of the scenario 4 (Figure 9d), respectively with 0.144 and $0.138 \mathrm{~km}^{2}$ invasion areas. Flow deposition values are superior (even up to $2 \mathrm{~m}$ ) to those of previous analyses because of the increase in volumetric amount related to the possible sediment load that each channel is able to take on. In both cases, the flow deposit reaches the minimum runout altitude of $408 \mathrm{~m}$ a.s.l.
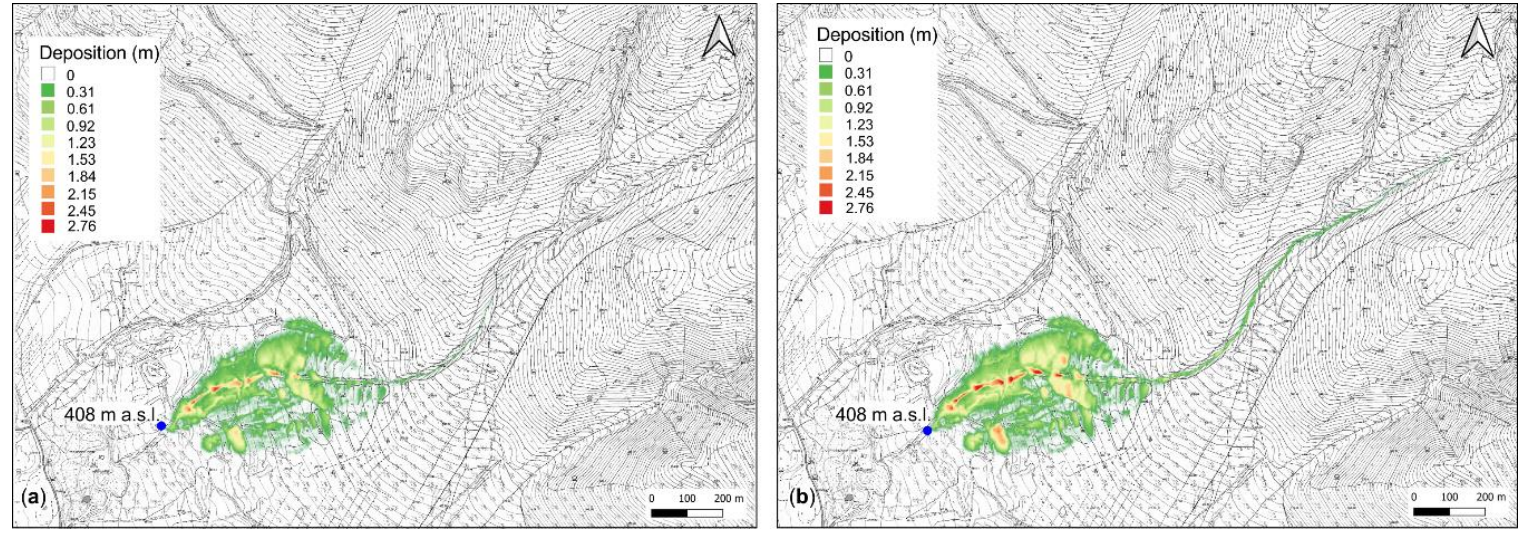

Figure 10. Colle della Croce flow deposition $(\mathrm{m})$ in scenario $5(\mathbf{a})$; scenario $6(\mathbf{b})$. The altitude points (blue dots) refer to the minimum runout altitude of each scenario.

\subsubsection{Total Channels Analysis}

One single release area was realized in order to investigate the possible invasion area of debris flow events assuming that they are triggered at the same time along each of the four selected channels (scenario 7).

In this hypothetical case, the debris flow invasion area $\left(0.144 \mathrm{~km}^{2}\right)$ is again located in NE of the Schiappara area ( $415 \mathrm{~m}$ a.s.l.). Here, the deposition values reach the maximum values $(>3 \mathrm{~m})$ if we compare it with those obtained in the previous analyses (Figure 11). In this case, a new invasion area $\left(0.049 \mathrm{~km}^{2}\right)$ is found at $500 \mathrm{~m}$ a.s.l., in the eastern part of the main debris flow mass which does not exceed $0.73 \mathrm{~m}$ in thickness. 


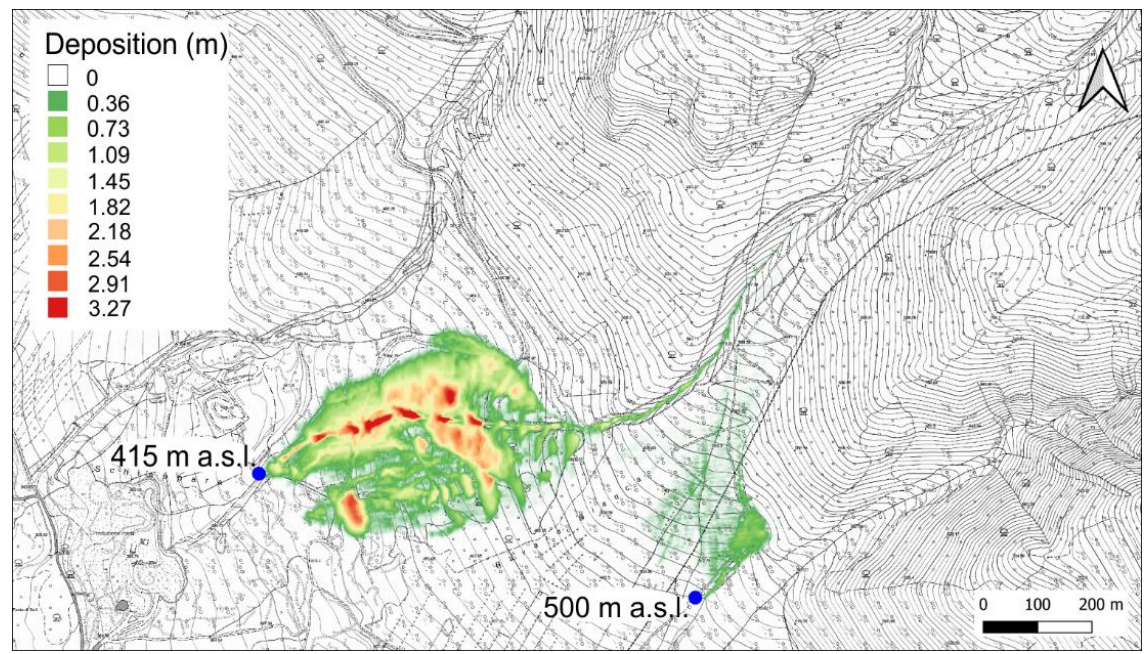

Figure 11. Colle della Croce flow deposition (m) in scenario 7. The altitude points (blue dots) refer to the minimum runout altitude.

\subsection{Pacentro Results}

The RAMMS simulations showed that the highest deposition values are recorded in correspondence with the debris flow invasion areas placed downstream (Figure 12).

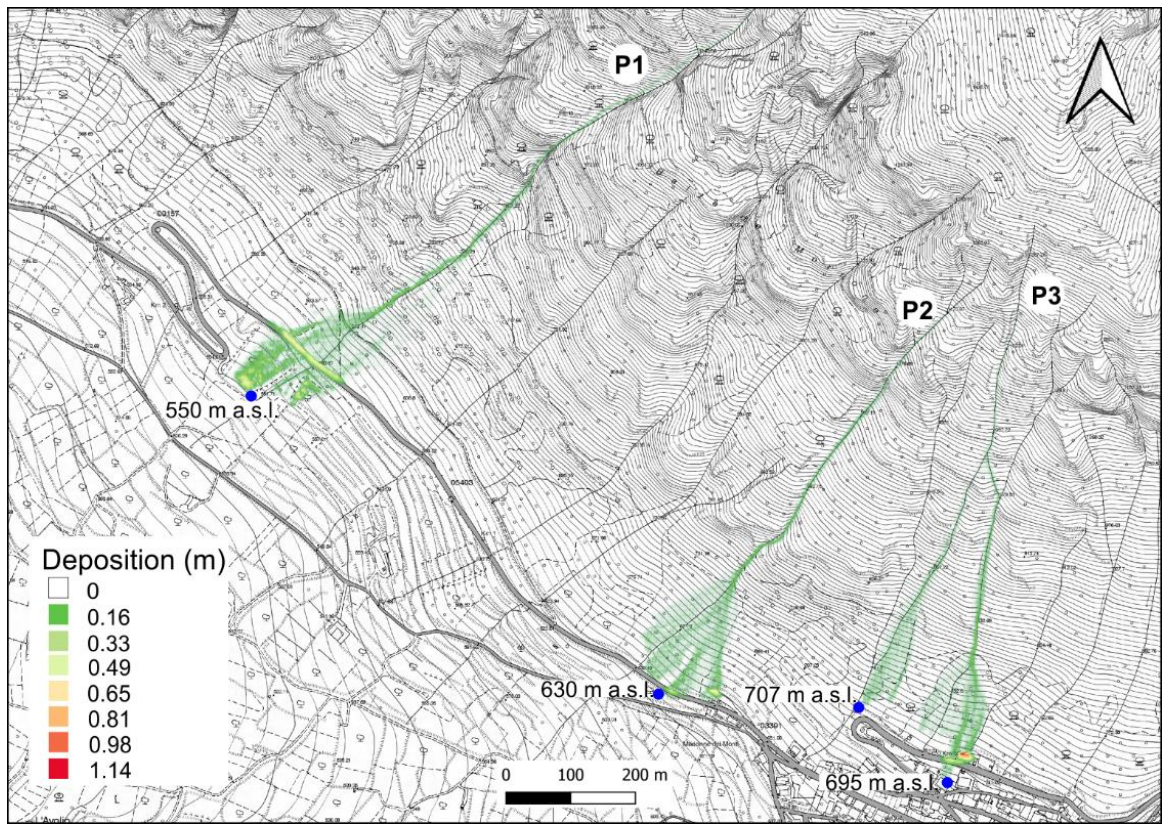

Figure 12. Pacentro, debris-flow deposition in P1; P2; P3 (located in Figure 6). The altitude points (blue dots) refer to the minimum runout altitude of each scenario.

The sediment thickness does not exceed $0.62 \mathrm{~m}$ in thickness in P1, $0.58 \mathrm{~m}$ in P2, and $1.14 \mathrm{~m}$ in P3 (Figure 12). The debris flow mass involves the SP n.13 road ( 600-700 m a.s.l.) and some buildings rising next to it.

In scenario 3, the debris flow mass splits into two channels and it shows the greatest thicknesses at the base of the easternmost channel. All the values of invasion areas and minimum runout altitudes are resumed in Table 4.

When performing the Rockyfor3D simulations and considering the cases 1 and $2(1 \times 0.7 \times 0.5$ with $+/-20 \%$ volume variation), a great number of blocks is found inside the main incisions in 
the slope and the distribution of the blocks is numerically higher when the slope has no vegetation cover (Figure 13a,b). The blocks stop at slope base involving the provincial and regional roads to Pacentro (SP. N.13, SR n. 487) and the buildings placed at higher topographic altitudes next to Pacentro village. When considering the cases 3 and $4(0.2 \times 0.2 \times 0.2$ with $+/-50 \%$ volume variation $)$, lower areal distribution and propagation of the blocks with respect to previous scenarios are evidenced (Figure 13c,d). Blocks stopped along the slope in larger quantities than in previous scenarios, not affecting the anthropic elements. The simulations carried with medium-large sized blocks and without vegetation covers were the heaviest for the assessment of the potential invasion areas.
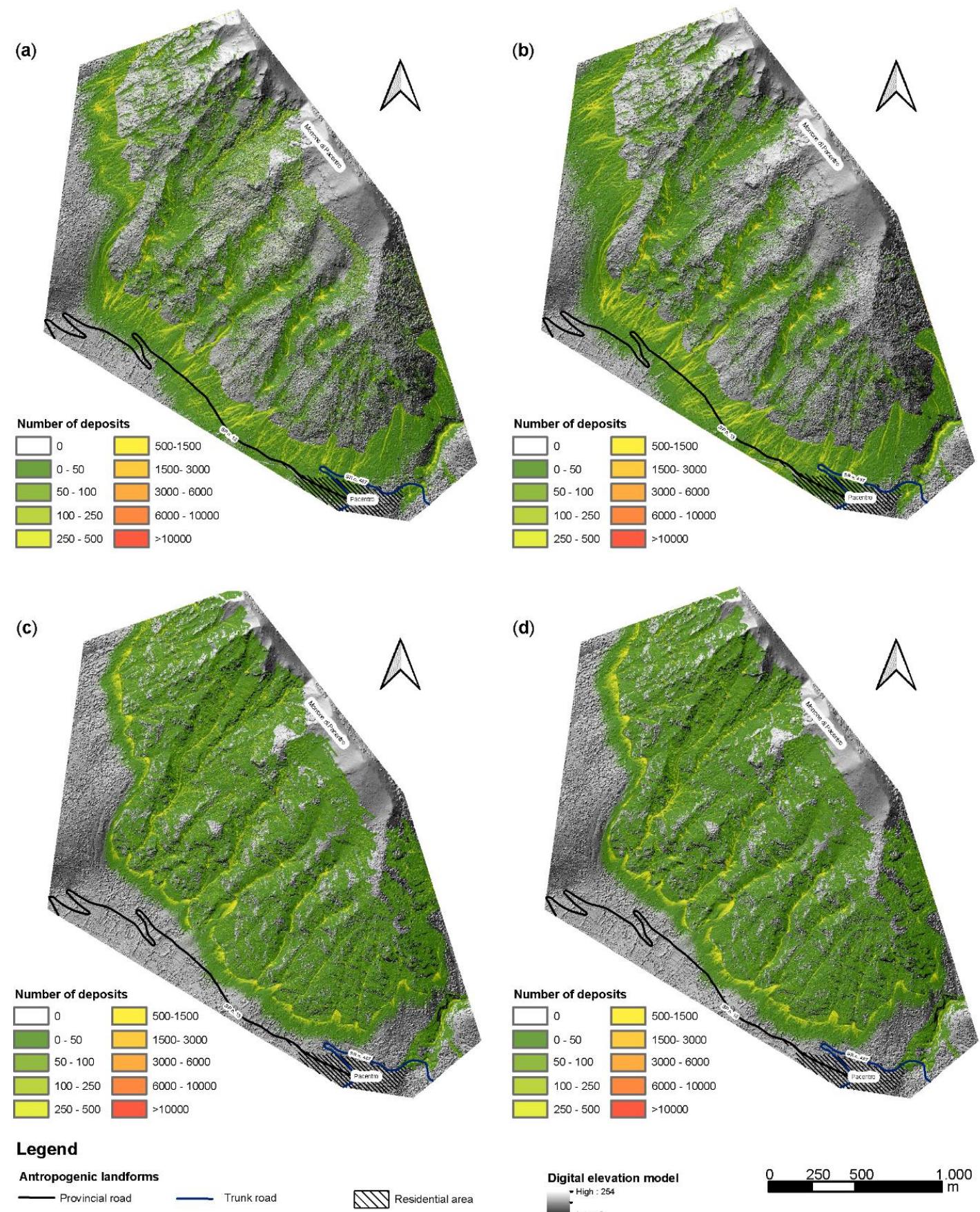

Legend

Antropogenic landforms

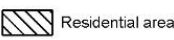

Figure 13. Rockyfor3D simulations next to the Pacentro area: stop zones of the blocks in case 1 (a); stop zones of the blocks in case 2 (b); stop zones of the blocks in case 3 (c); stop zones of the blocks in case 4 (d). 
Table 4. Invasion areas and minimum runout altitudes of Pacentro scenarios.

\begin{tabular}{ccc}
\hline Pacentro & $\begin{array}{c}\text { Minimum } \\
\text { Runout Altitude (m a.s.l.) }\end{array}$ & Invasion Area $\left.\mathbf{( k m}^{\mathbf{2}}\right)$ \\
\hline P1 & 455 & 0.016 \\
P2 & 438 & 0.020 \\
P3 & 695 & 0.028 \\
\hline
\end{tabular}

\section{Discussion}

This paper focuses on the landslide hazard assessment of the SW escarpment of the Montagna del Morrone (Abruzzo Region, Central Italy), where gravitational processes, mainly related to well-documented rockfall and debris flows events, occurred several times in the past, as well as seismic events, debris avalanches, and fires.

The integration of field (i.e., morphometric and slope analyses, geological and geomorphological field surveys, geomechanical investigation) and remote (orthophoto interpretation and UAV survey) [13] investigations, combined with RAMMS and Rockyfor3D numerical modeling, supported the evaluation of rockfalls and debris flow hazard assessment of the ridge. This study allowed to investigate the most critical and failure areas, the blocks trajectory, and certain and/or possible invasion areas of the blocks which can compromise the safety of the urban and infrastructural settlements present in the area.

The overall analysis confirms that the landscape changes of the studied sectors of the SW escarpment of the Montagna del Morrone ridge is connected to gravity-induced processes, mainly related to debris flow and rockfall events. The debris flow and rockfall hazard assessment in these areas were evaluated respectively through RAMMS and Rockyfor3D numerical modeling simulations. The obtained results, as well as field observations, allowed to outline the sectors of the ridge characterized by critical stability conditions, which may compromise people's safety.

In detail, RAMMS analyses revealed that the extension of debris flow invasion areas in the Colle della Croce sector varies according to the different scenarios analyzed. Indeed, the accumulation areas are minor when the debris flows develop on the single channels, greater when the modeling is performed on pairs of channels, maximum when all the channels are considered together. The minimum runout altitudes of each scenario (Figures 9-11) are showed in Table 5.

Table 5. Invasion areas and minimum runout altitudes of Colle della Croce scenarios.

\begin{tabular}{ccc}
\hline Colle della Croce & $\begin{array}{c}\text { Minimum } \\
\text { Runout Altitude (m a.s.l.) }\end{array}$ & Invasion Area $\mathbf{( k m}^{\mathbf{2}} \mathbf{)}$ \\
\hline Scenario 1 & 455 & 0.038 \\
Scenario 2 & 438 & 0.064 \\
Scenario 3 & 455 & 0.040 \\
Scenario 4 & 410 & 0.124 \\
Scenario 5 & 408 & 0.144 \\
Scenario 6 & 408 & 0.138 \\
Scenario 7 & 415 & 0.193 \\
\hline
\end{tabular}

Debris flow events in the Pacentro area involve the SP n.13 road and the structures rising next to it (Figure 14). RAMMS simulation results show that the debris flows stop at the base of the slope, at altitudes comparable with those of the areas where rockfall blocks also stop.

When Rockyfor3D simulations were carried out in the Pacentro area, cases with medium-large sized blocks (with and without vegetation covers) showed that the invasion areas reach the slope base involving the SP. n.13 and SR n.487 roads to Pacentro. When modest-sized blocks simulations were carried out, potential invasion areas are found again at the base of the slope, but they are smaller and marginally invade the aforementioned roadways. In order to analyze more specifically the extension 
of the invasion areas, RAMMS simulations along the selected channels (P1, P2, P3 in Figure 8) and Rockyfor3D results were overlaid in GIS technology (Figures 15-17).


Figure 14. 2017 Debris flow event: detail of the invasion area (a,b); (c) rock blocks behind the guard rail of the SP n.13 road.
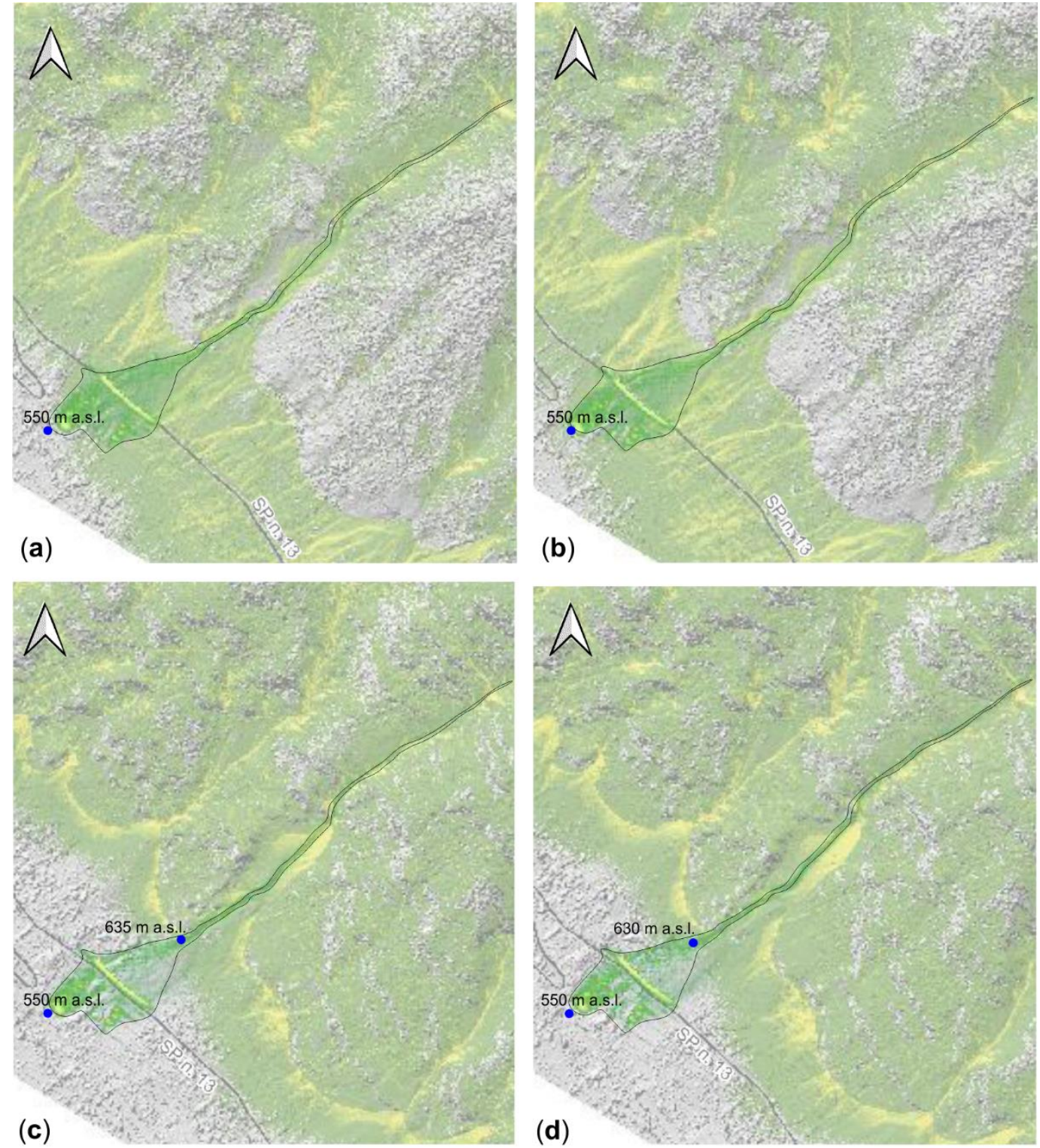

Figure 15. Comparison between the P1 RAMMS simulation and the Rockyfor3D case 1 (a), case 2 (b), case 3 (c), case 4 (d). The altitude points (blue dots) refer to the minimum runout altitude of each scenario. 

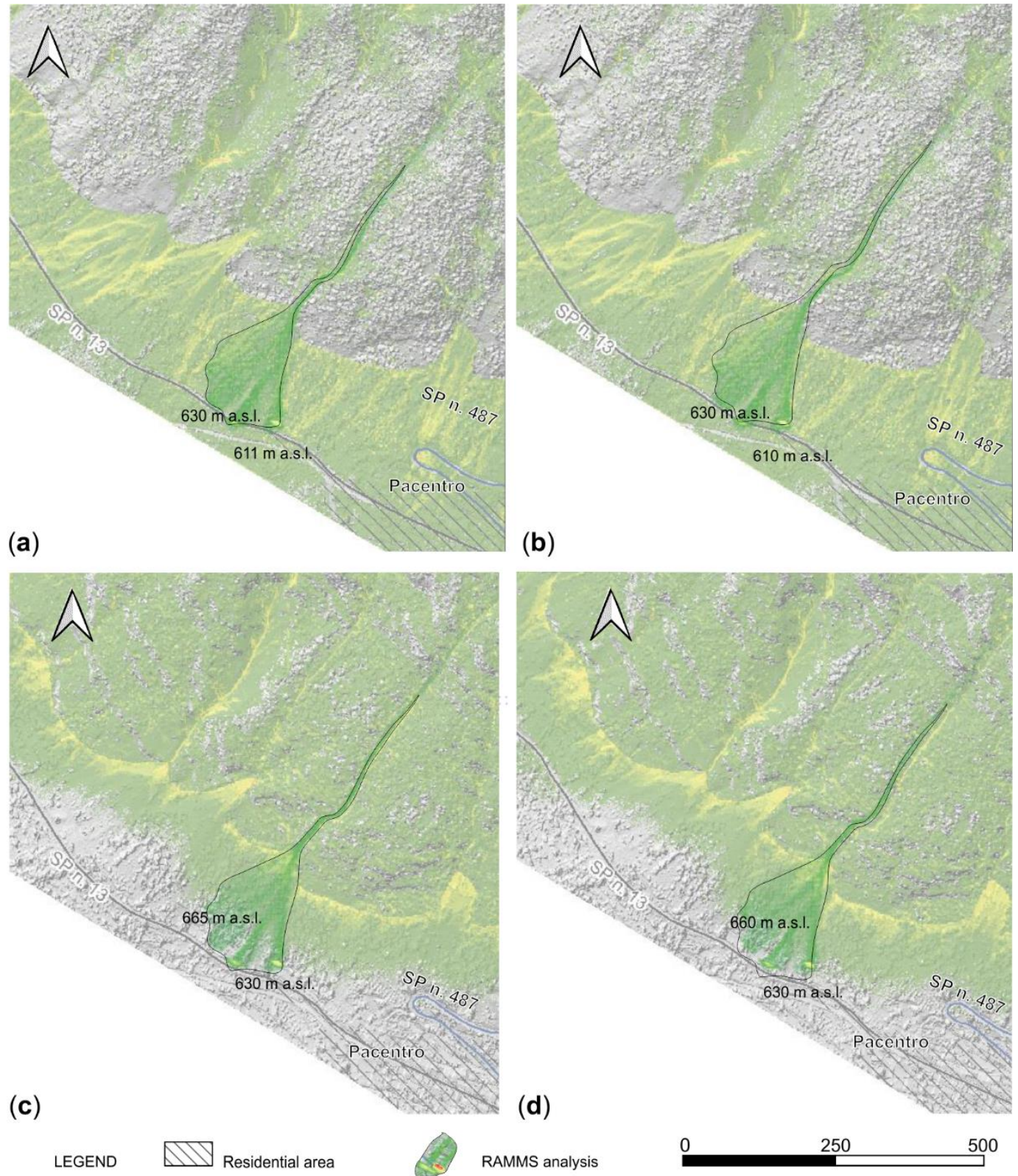

LEGEND RIV Residential area

RAMMS analysis

00

Figure 16. Comparison between the P2 RAMMS simulation and the Rockyfor3D case 1 (a), case 2 (b), case 3 (c), case 4 (d). The altitude points (blue dots) refer to the minimum runout altitude of each scenario. 

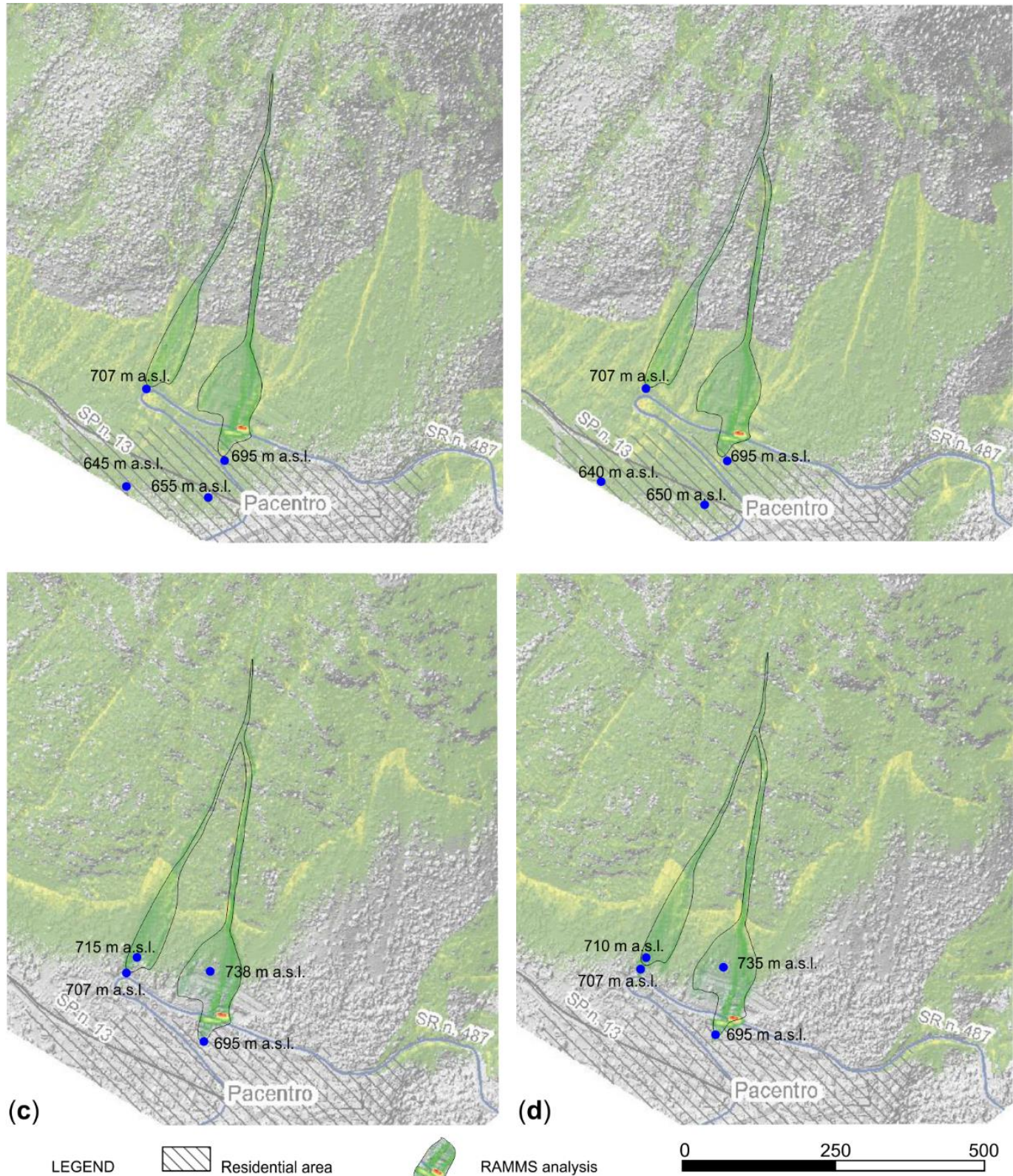

LEGEND

Residential area

RAMMS analysis

00

Figure 17. Comparison between the P3 RAMMS simulation and the Rockyfor3D case 1 (a), case 2 (b), case3 (c), case 4 (d). The altitude points (blue dots) refer to the minimum runout altitude of each scenario.

Considering P1 scenario (Figure 15), the minimum runout altitude obtained through RAMMS corresponds to those of cases n. 1 and n. 2 (medium-large blocks-with and without vegetation) obtained with Rockyfor3D (Table 6).

Table 6. Minimum runout altitude in P1.

\begin{tabular}{ccc}
\hline \multicolumn{2}{c}{ Minimum Runout Altitude (m a.s.1.) } \\
\hline RAMMS & \multicolumn{2}{c}{ Rockyfor3D } \\
\hline 550 & Case 1 & 550 \\
550 & Case 2 & 550 \\
550 & Case 3 & 635 \\
550 & Case 4 & 630 \\
\hline
\end{tabular}


When P2 and P3 scenarios were compared with Rockyfor3D results (Figures 16 and 17), the minimum runout altitudes obtained with RAMMS are intermediate to those of cases n. 3 and n. 4 (modest sized blocks-with and without vegetation) estimated with Rockyfor3D simulations (Tables 7 and 8).

Table 7. Minimum runout altitude in P2.

\begin{tabular}{ccc}
\hline \multicolumn{3}{c}{ Minimum Runout Altitude (m a.s.1.) } \\
\hline RAMMS & \multicolumn{2}{c}{ Rockyfor3D } \\
\hline 630 & Case 1 & 611 \\
630 & Case 2 & 610 \\
630 & Case 3 & 665 \\
630 & Case 4 & 660 \\
\hline
\end{tabular}

Table 8. Minimum runout altitude in P3.

\begin{tabular}{cccc}
\hline & \multicolumn{2}{c}{ Minimum Runout Altitude (m a.s.1.) } \\
\hline & RAMMS & \multicolumn{2}{c}{ Rockyfor3D } \\
\hline \multirow{3}{*}{ Eastern channel } & 695 & Case 1 & 655 \\
& 695 & Case 2 & 650 \\
& 695 & Case 3 & 738 \\
& 695 & Case 4 & 735 \\
\hline \multirow{3}{*}{ Western channel } & 707 & Case 1 & 645 \\
& 707 & Case 2 & 640 \\
& 707 & Case 3 & 715 \\
& 707 & Case 4 & 710 \\
\hline
\end{tabular}

In conclusion, the most critical and precautionary conditions next to Pacentro sector are represented by Rockyfor3D simulations with medium-large blocks (cases 1 and 2).

The geological and geomorphological field survey, integrated with photogeological interpretation, geomechanical investigation, and reported events analysis, is vital for a correct investigation of the rockfall and debris flow hazard assessment. This approach allowed the individuation of the main hypothetical release areas of specific slope sectors where topographic, lithological, and geomorphological variations control the rockfall and debris flow development. Field surveys allowed to identifying the main critical areas where these types of landslide mechanisms are expected, as well as to achieve effective results when applying numerical modeling for rockfall (Rockyfor3D) and debris flow (RAMMS) investigation. Numerical modeling results confirmed that the critical areas selected through field observations are affected by rockfall and debris flow events.

This method provides an effective tool to support the hazard assessment in mountain areas, strongly improving the identification of the landscape changes.

According to the obtained results, for the northern part of the Montagna del Morrone, it is possible to define a respect zone of debris flow invasion areas from 408 to $360 \mathrm{~m}$ a.s.l. (average altitude of the Sulmona plain); while for the southern part of the Montagna del Morrone, the respect zone of rockfall invasion areas is from 550 to $360 \mathrm{~m}$ a.s.l. (average altitude of the Sulmona plain). These respect zones are indispensable for the correct territorial planning and management of the infrastructural settlements present in the area.

Author Contributions: Funding acquisition: N.S. and E.M.; Conceptualization and Methodology: E.M. and N.S.; Investigation: V.M. (Valeria Menna), V.M. (Vania Mancinelli) and M.C.; Software: M.C., V.M. (Valeria Menna) and V.M. (Vania Mancinelli); Supervisions: E.M. and N.S.; Writing-Original draft: M.C. and V.M. (Valeria Menna); Writing-Final version: N.S., E.M., M.C., V.M. (Valeria Menna) and V.M. (Vania Mancinelli). All authors have read and agreed to the published version of the manuscript. 
Funding: This work was supported by the Università degli Studi "G. d'Annunzio" Chieti Pescara funds (Monia Calista, Enrico Miccadei and Nicola Sciarra funds).

Acknowledgments: The authors wish to thank the Municipalities of Pacentro. The authors also wish to thank the Cartographic Office of the Abruzzo Region by means of the Open Geodata Portal (http://opendata.regione. abruzzo.it/) and the Ministero dell'Ambiente e della Tutela del Territorio e del Mare (http://www.minambiente.it/), for providing the topographic data, LIDAR, aerial photos and orthophotos used for this work. The rainfall data were provided by the Functional Center and Hydrographic O_ce of the Abruzzo Region (Centro Funzionale e U_cio Idrografico Regione Abruzzo). The 20 m SINAnet (Sistema Informativo Nazionale Ambientale) DEM was provided by ISPRA (http://www.sinanet.isprambiente.it/it/sia-ispra/downloadmais/dem20/view).

Conflicts of Interest: The authors declare no conflict of interest.

\section{References}

1. Guzzetti, F.; Reichenbach, P.; Cardinali, M.; Galli, M.; Ardizzone, F. Probabilistic landslide hazard assessment at the basin scale. Geomorphology 2005, 72, 272-299. [CrossRef]

2. Aleotti, P.; Chowdhury, R. Landslide hazard assessment: Summary review and new perspectives. Bull. Eng. Geol. Environ. 1999, 58, 21-44. [CrossRef]

3. Von Ruette, J.; Lehmann, P.; Or, D. Rainfall-triggered shallow landslides at catchment scale: Threshold mechanics-based modeling for abruptness and localization. Water Resour. Res. 2013, 49, 6266-6285. [CrossRef]

4. Crosta, G.B.; Frattini, P. Distributed modelling of shallow landslides triggered by intense rainfall. Nat. Hazards Earth Syst. Sci. 2003, 3, 81-93. [CrossRef]

5. D'Alessandro, L.; Miccadei, E.; Piacentini, T. Morphostructural elements of central-eastern Abruzzi: Contributions to the study of the role of tectonics on the morphogenesis of the Apennine chain. Quat. Int. 2003, 101-102, 115-124. [CrossRef]

6. Parotto, M.; Cavinato, G.P.; Miccadei, E.; Tozzi, M. Line CROP 11: Central Apennines. In CROP Atlas: Seismic Reflection Profiles of the Italian Crust; Scrocca, D., Doglioni, C., Innocenti, F., Manetti, P., Mazzotti, A., Bertelli, L., Burbi, L., D’O_zi, S., Eds.; Memorie Descrittive della Carta Geologica d'Italia: Rome, Italy, 2004; Volume 6, pp. 145-153.

7. Ciccacci, S.; D'Alessandro, L.; Dramis, F.; Miccadei, E. Geomorphologic evolution and neotectonics of the Sulmona intramontane basin (Abruzzi Apennine, Central Italy). Z. Geomorphol. Suppl. 1999, 118, $27-40$.

8. Calista, M.; Miccadei, E.; Pasculli, A.; Piacentini, T.; Sciarra, M.; Sciarra, N. Geomorphological features of the Montebello sul Sangro large landslide (Abruzzo, Central Italy). J. Maps 2016, 12, 882-891. [CrossRef]

9. Piacentini, T.; Miccadei, E. The role of drainage systems and intermontane basins in the Quaternary landscape of the Central Apennines chain (Italy). Rend. Lincei 2014, 25, 139-150. [CrossRef]

10. Beneo, E. Sezioni geologiche attraverso la Montagna del Morrone (Appennino Abruzzese). Boll. Reg. Uff. Geo. d'It. 1939, 64, 1-17.

11. Vezzani, L.; Ghisetti, F. Domini in compressione e in distensione al retro dei fronti del Gran Sasso-M. Picca e del M. Morrone: Il ruolo della zona di taglio Avezzano-Bussi (Appennino centrale). Studi Geol. Camerti 1995, 475-490. [CrossRef]

12. Miccadei, E.; Barberi, R.; Cavinato, G.P. La geologia quaternaria della Conca di Sulmona (Abruzzo, Italia centrale). Geol. Romana 1999, 34, 58-86.

13. Carabella, C.; Miccadei, E.; Paglia, G.; Sciarra, N. Post-Wildfire Landslide Hazard Assessment: The Case of The 2017 Montagna Del Morrone Fire (Central Apennines, Italy). Geosciences 2019, 9, 175. [CrossRef]

14. Rickenmann, D. Empirical relationship for debris flows. Nat. Hazards 1999, 19, 47-77. [CrossRef]

15. Dorren, L.K.A.; Simoni, S. Rockyfor3D (v 5.1) Rivelato-Descrizione Trasparente del Modello 3D di Caduta Massi; EcorisQ: Ginevra, Switzerland, 2014; 27p.

16. Frattini, P.; Crosta, G.B.; Carrara, A.; Agliardi, F. Assessment of rockfall susceptibility by integrating statistical and physically-based approaches. Geomorphology 2008, 94, 419-437. [CrossRef]

17. Scarascia Mugnozza, G.; Bianchi Fasani, G.; Esposito, C. Le frane catastrofiche in roccia: Un fattore di rischio in Appennino? S.L.M. Riv. dell'IMONT 2006, 27, 14-21.

18. Budetta, P. Assessment of rock fall risk along roads. Nat. Hazards Earth Syst. Sci. 2004, 4, 71-81. [CrossRef]

19. Piacentini, T.; Miccadei, E.; Di Michele, R.; Sciarra, N.; Mataloni, G. Geomorphological analysis applied to rock falls in Italy: The case of the San Venanzio gorges (Aterno river, Abruzzo, Italy). Ital. J. Eng. Geol. Environ. 2013, 6, 467-479. 
20. Miccadei, E.; Paron, P.; Piacentini, T. The SW escarpment of Montagna del Morrone (Abruzzi, Central Italy): Geomorphology of a fault-generated mountain front. Geogr. Fis. Din. Quat. 2004, 27, 55-87.

21. Rovida, A.; Locati, M.; Camassi, R.; Lolli, B.; Gasperini, P. CPTI15-2015 Version of the Parametric Catalogue of Italian Earthquakes; INGV: Rome, Italy, 2016.

22. Miccadei, E.; Piacentini, T.; Barbieri, R. Studi Geologici Camerti. In Uplift and local tectonic subsidence in the evolution of intramontane basins: The example of the Sulmona basin (Central Apennines, Italy), Proceedings of the International INQUA Workshop "Large-scale vertical movements and related gravitational processes". Camerino, Rome, 21-26 June 1999; Special Issue 2002; Dramis, F., Farabollini, P., Molin, P., Eds.; Università di Camerino: Camerino, Italy, 2002; pp. 119-133.

23. Planhol, X.D. Demangeot (Jean). Géomorphologie des Abruzzes adriatiques (Mémoires et Documents du Centre de Recherches et Documentation cartographiques et géographiques, numéro hors série). Rev. Géographique de l'Est 1966, 6, 224-225.

24. Sciarra, N.; Miccadei, E.; Piacentini, T.; Carabella, C.; Paglia, G.; Buccolini, M. Analisi di Valutazione Della Pericolosità e del Rischio Idrogeologico Nelle aree Percorse da Incendi Boschivi Nell'area della Montagna Morrone a Seguito Degli Incendi Boschivi Verificatisi Nell'anno 2017. DGR n. 1001 del 20/12/2018. Available online: https://www.regione.abruzzo.it/content/dgr-n-1001-del-20/12/2018 (accessed on 11 October 2019).

25. CNR-GNDCI. Progetto AVI: Censimento delle aree italiane vulnerate da calamità idrogeologiche. Rapporto di sintesi Abruzzo. Presidenza del consiglio dei Ministri, Dipartimento della Protezione Civile. 1998. Available online: avi.gndci.cnr.it (accessed on 15 January 2020).

26. ISPRA. Istituto Superiore per la Protezione e la Ricerca Ambientale-Annuario dei Dati Ambientali. Available online: https://annuario.isprambiente.it/ada/basic/6865 (accessed on 3 February 2020).

27. Cartographics Office of Abruzzo Region-Open Geodata Portal. Available online: http://opengeodata. regione.abruzzo.it (accessed on 9 October 2019).

28. Report-Age. Available online: https://report-age.com (accessed on 7 January 2020).

29. Pellegrini, G.B.; Carton, A.; Castaldini, D.; Cavallin, A.; D’alessandro, L.; Dramis, F.; Gentili, B.; Laureti, L.; Prestininzi, A.; Rodolfi, G.; et al. Proposta di legenda geomorfologica ad indirizzo applicativo. Geogr. Fis. Din. Quat. 1993, 16, 129-152.

30. SGN. Guida al Rilevamento della Carta Geomorfologica D'ITALIA, 1:50.000; Quad. Ser. III del Serv. Geol. Naz.; Servizio Geologico d'IItalia: Rome, Italy, 1994.

31. Hungr, O.; Morgan, G.; Kellerhals, R. Quantitative analysis of debris torrent hazards for design of remedial measures. Can. Geotech. J. 1984, 21, 663-677. [CrossRef]

32. Mizuyama, T.; Kobashi, S.; Ou, G. Prediction of debris flow peak discharge. In Proceedings of the International Symposium Interpraevent, Bern, Switzerland, 29 June-3 July 1992.

33. Simoni, A.; Mammoliti, M.; Graf, C. Performance of 2D debris flow simulation model RAMMS. Back-analysis of field events in Italian Alps. In Proceedings of the Annual International Conference on Geological and Earth Sciences GEOS 2012, Singapore, 3-4 December 2012.

34. Schraml, K.; Thomschitz, B.; McArdell, B.W.; Graf, C.; Kaitna, R. Modeling debris-flow runout patterns on two alpine fans with different dynamic simulation models. Nat. Hazards Earth Syst. Sci. 2015, 15, 1483-1492. [CrossRef]

35. User Manual, WSL Institute for Snow and Avalanche Research SLF, Davos, Birmensdorf, Switzerland. Available online: http://ramms.slf.ch/ramms/downloads/RAMMS_DBF_Manual.pdf (accessed on 2 October 2019).

36. Graf, C.; McArdell, B. Simulation of debris flow runout before and after construction of mitigation measures: An example from the Swiss Alps. In Proceedings of the International Conference on DEBRIS FLOWS: Disasters, Risk, Forecast, Protection, Pyatigorsk, Russia, 22-29 September 2008; pp. 233-236.

37. Krušić, J.; Abolmasov, B.; Marjanović, M.; Djurić, D. Numerical modelling in RAMMS—Selanac debris flow. In Proceedings of the Second JTC1 Workshop on Triggering and Propagation of Rapid Flow-like Landslides, Hong Kong, 3-5 December 2018.

38. Frank, F.; McArdell, B.; Huggel, C.; Vieli, A. The importance of entrainment and bulking on debris flow runout modeling: Examples from the Swiss Alps. Nat. Hazards Earth Syst. Sci. 2015, 15, 2569-2583. [CrossRef]

39. Rodriguez-Morata, C.; Villacorta, S.; Stoffel, M.; Ballesteros-Canovas, J. Assessing strategies to mitigate debris-flow risk in Abancay province, south-central Peruvian Andes. Geomorphology 2019, 342. [CrossRef] 
40. Gan, J.J.; Zhang, Y.X. Numerical Simulation of Debris Flow Runout Using Ramms: A Case Study of Luzhuang Gully in China. Comput. Modeling Eng. Sci. 2020. [CrossRef]

41. ecorisQ (International Association for Natural Hazard Risk Management). Available online: http://www. ecorisq.org/ (accessed on 4 February 2016).

42. Heinimann, H.R.; Holtenstein, K.; Kienholz, H.; Krummenhacher, B.; Mani, P. Methoden zur analyse und Bewertung von Naturgefahren. Umw. Mater. 1998, 85, 248.

(c) (1)

(C) 2020 by the authors. Licensee MDPI, Basel, Switzerland. This article is an open access article distributed under the terms and conditions of the Creative Commons Attribution (CC BY) license (http://creativecommons.org/licenses/by/4.0/). 